\title{
OCCUPATIONAL ASTHMA CAUSED BY SAMBA (TRIPLOCHITON SCLEROXYLON) WOOD DUST IN A PROFESSIONAL MAKER OF WOODEN MODELS OF AIRPLANES: A CASE STUDY
}

\section{PATRYCJA KRAWCZYK-SZULC ${ }^{1}$, MARTA WISZNIEWSKA ${ }^{1}$, CEZARY PAŁCZYŃSKI ${ }^{2}$, EWA NOWAKOWSKA-ŚWIRTA ${ }^{2}$, ANNA KOZAK ${ }^{1}$, and JOLANTA WALUSIAK-SKORUPA ${ }^{1}$}

${ }^{1}$ Nofer Institute of Occupational Medicine, Łódź, Poland

Department of Occupational Diseases and Clinical Toxicology

${ }^{2}$ Nofer Institute of Occupational Medicine, Łódź, Poland

Department of Allergology and Environmental Health

\begin{abstract}
Objectives: Wood dust is a known occupational allergen that may induce, in exposed workers, respiratory diseases including asthma and allergic rhinitis. Samba (obeche, Triplochiton scleroxylon) is a tropical tree, which grows in West Africa, therefore, Polish workers are rarely exposed to it. This paper describes a case of occupational asthma caused by samba wood dust. Material and Methods: The patient with suspicion of occupational asthma due to wood dust was examined at the Department of Occupational Diseases and Clinical Toxicology in the Nofer Institute of Occupational Medicine. Clinical evaluation included: analysis of occupational history, skin prick tests (SPT) to common and occupational allergens, determination of serum specific IgE to occupational allergens, serial spirometry measurements, metacholine challenge test and specific inhalation challenge test with samba dust. Results: SPT and specific serum IgE assessment revealed sensitization to common and occupational allergens including samba. Spirometry measurements showed mild obstruction. Metacholine challenge test revealed a high level of bronchial hyperactivity. Specific inhalation challenge test was positive and cellular changes in nasal lavage and induced sputum confirmed allergic reaction to samba. Conclusions: IgE mediated allergy to samba wood dust was confirmed. This case report presents the first documented occupational asthma and rhinitis due to samba wood dust in wooden airplanes model maker in Poland.
\end{abstract}

Key words:

Occupational asthma, Wood dusts, Samba, Triplochiton scleroxylon, Specific inhalation challenge test

\section{OBJECTIVES}

In Europe, over 3 million people work in wood industry in exposure to wood dust [1]. Bronchial asthma is one of the most frequent health problems in this population its prevalence is twice as high as it is in the non-exposed one [2]. In this population also a higher risk of developing bronchitis and impaired spirometry can be observed [3].
Asthma may be induced by wood dust of various tree species such as: red cedar tree, beech, oak, samba, iroko (kambala) [4-7]. It is estimated that about $6-15 \%$ of woodworkers suffer from bronchial asthma [8].

In Poland, exotic species of trees are used in the industry and in the model making more and more frequently. The example of such a material is samba (Triplochiton

Received: June 4, 2012. Accepted: February 12, 2014.

Corresponding author: P. Krawczyk-Szulc, Department of Occupational Diseases and Clinical Toxicology, Nofer Institute of Occupational Medicine, św. Teresy 8 , 91-348 Łódź, Poland (e-mail: patunia@imp.lodz.pl). 
scleroxylon) from West Africa, also known as an African maple. Wood of the samba tree is soft, with a great resistance, and it is frequently used for the production of wooden frames, boxes and saunas. Samba may be also useful in model making. Wood dust particles belong to the low molecular weight (LMW) allergens and like other allergens from this group cause mainly IgE-independent reactions [9]. However, there are data confirming that allergens of samba wood - as one of the exceptions - may also cause IgE-dependent reactions [10,11].

A patient with suspicion of occupational asthma due to wood dust was admitted to the Department of Occupational Diseases and Clinical Toxicology in the Nofer Institute of Occupational Medicine. That was a 48-year-old patient who had been working in the factory producing airplanes, at first as a turner and then for the next 7 years as a former, among others in the production of forms of airplanes' models. At work he was exposed to wood dust, including samba, lime and pine tree, but also to polyester epoxy resins, polystyrene, paints and varnishes. The patient had a 35 pack-years history of smoking. He quitted smoking 9 months before being admitted to the Clinic. Family history of allergy was negative. According to the history, the first respiratory symptoms were shortness of breath, periodical dry cough, sneezing, rhinorrhea, which started after 27 years of work. At the beginning, the symptoms occurred only at work and were becoming less intensive at home. In the patient's opinion, the symptoms were related to exposure to epoxy resins and paints present in the workplace. The symptoms improved at the weekends and during holidays.

During the last 5 months before admission to the Department, the patient observed a significant exacerbation of respiratory symptoms. The cough and dyspnea developed immediately after entering the workplace, where processes of laminating were held. At the Regional Centre of Occupational Medicine the patient was examined by a pulmonologist and atopic asthma was recognized. However, further diagnostics was needed due to occupational exposure to epoxy resins. Therefore, the patient was referred to our Department. On admission, the patient reported: shortness of breath, chest pain, periodical dry cough, sneezing, rhinorrhoea and watering of eyes. Auscultation revealed only sharpening of the vesicular rustle and single whirring.

\section{MATERIAL AND METHODS}

\section{Skin prick tests}

Skin prick tests (SPT) to common allergens (dust mites, feathers, grass/weed/tree pollens, moulds) were performed with application of extracts produced by Allergopharma. SPT to wood dust (pine, spruce, oak, beech, samba) were performed by the use of Allergopharma extracts and standardized extracts prepared by the Laboratory of the Institute of Immunology and Allergology (Institut für Prävention und Arbeitsmedizin der Deutschen Gesetzlichen Unfallversicherung Institut der Ruhr-Universität Bochum (IPA)) in Bochum, Germany.

The negative control was the allergen diluent and the positive control - $1 \mathrm{mg} / \mathrm{ml}$ metacholine dihydrochloride solution. The largest wheal diameter was assessed after $15 \mathrm{~min}$. A wheal diameter of $\geq 3 \mathrm{~mm}$ and equal to or greater than half of that formed by histamine was defined as positive, indicating sensitization.

Spirometry measurements were carried out on the Vicatest equipment (Mijnhardt, Holland) immediately before specific inhalation challenge test (SICT) and after 5 min as well as in the 1st, 2nd, 4th, 5th, 24th h after. Simultaneously, the variability of peak expiratory flow (PEF) was monitored before and after SICT, every hour during 24-h observation.

Bronchial reversibility was assessed by administration of short-acting $\beta 2$ agonist (bronchodilator) - $400 \mathrm{mg}$ of salbutamol. Improvements in forced expiratory volume in the 1 st $\mathrm{s}\left(\mathrm{FEV}_{1}\right)>12 \%$ and $>200 \mathrm{ml}$ after $15 \mathrm{~min}$ was recorded as a positive result [12]. 


\section{Serum IgE level}

Total serum immunoglobulin E ( $\operatorname{IgE})$ and specific serum $\operatorname{IgE}(\mathrm{sIgE})$ for pine, oak, samba allergens, dust mites, synthetic fibers and formaldehyde were determined (Immunocap, Phadia, Sweden).

\section{Metacholine challenge test}

Metacholine challenge test by Cockroft for the evaluation of bronchial hyperresponsiveness (BHR) was performed [13]. Metacholine hydrochloride (Sigma Chemical Company, USA) solved in saline solutions was inhaled with growing concentrations of $0.03 ; 0.06 ; 0.125 ; 0.250$; $0.5 ; 1.0 ; 2.0 ; 4.0 ; 8.0$ and $16 \mathrm{mg} / \mathrm{ml}$ using the DeVilbiss 646 inhaler (USA). The test was interrupted if decrease of forced expiratory volume in the 1st second $\left(\mathrm{FEV}_{1}\right)$ was at least $20 \%$. The threshold value of reaction to metacholine was estimated from the logarithmic curve dose-reply, appointing the metacholine concentration causing the $20 \%$ decrease of $\mathrm{FEV}_{1}(\mathrm{PC} 20 \mathrm{H})$.

\section{Specific inhalation challenge test (SICT)}

Standardized extract of wood dust was not available so the SICT was conducted by simulating the patient's workplace conditions [14]. It was performed in a workplace simulation setting (room space $6 \mathrm{~m}^{2}$ with temperature $22-25^{\circ} \mathrm{C}$ ) with the patient's own samples. The patient was polishing samba wood pieces from his workplace for $30 \mathrm{~min}$, using the abrasive paper. The SICT was held under the surveillance of a physician, who noted all respiratory symptoms appearing during the test. On a day preceding conducting the specific inhalation challenge test, a provocation with placebo - potato flour was performed in the same conditions and at the same time. Before, $4 \mathrm{~h}$ and $24 \mathrm{~h}$ after the provocation a morphological evaluation of nasal lavage fluid was carried out. Moreover, before and $24 \mathrm{~h}$ after the SICT morphological changes of induced sputum were also assessed. The test was evaluated as positive, if $\mathrm{FEV}_{1}$ fell by $\geq 20 \%$ of the baseline value in the absence of any change in response to a control challenge or 3-fold increase in BHR level was observed.

\section{Morphological evaluation of nasal lavage fluid and induced sputum}

All the procedures were performed as in the 'nasal pool' method. Nasal lavage fluid was whirled for $10 \mathrm{~min}$ with rotational speed of $1000 / \mathrm{min}$. Then cellular precipitate was washed in a buffered saline solution (PBS, Sigma, USA), and finally it was put in $1 \mathrm{ml}$ of farm RPMI base (Sigma USA). The cells were dyed using May-Grünewald-Giemsa method and toluidine blue and then they were counted in the Fuchs-Rosenthal's Chamber. A total number of leukocytes was indicated, as well as the amount of eosinophilic and basophilic white cells. The precipitate was whirled again for $10 \mathrm{~min}$ with rotational speed of $600 / \mathrm{min}$ and it was dyed using Giemsa method. Proportional composition of cells was evaluated by estimation of 200 cells and indication of the epithelium, neutrophilic, eosinophilic, basophilic cells, monocytes and lymphocytes.

\section{RESULTS}

Skin prick tests to common aeroallergens were positive with various species of dust mites, grass and trees pollens, cat's fur and with the samba wood dust, while SPT results to wood dusts of spruce, oak, pine, fir and beech were negative. Total serum immunoglobulin E ( $\mathrm{IgE}$ ) level was $135.42 \mathrm{kU} / \mathrm{l}$. Increased specific serum IgE to occupational allergens was also found (Table 1).

Spirometry measurements revealed FVC - $4.511(91 \%$ of predicted values), $\mathrm{FEV}_{1}-2.85$ (70\%), Tiffeneau index $-63 \%$. The patient exhibited bronchodilator reversibility by $15 \% \mathrm{FEV}_{1}$ increase compared to the baseline. The non-specific inhalation challenge test with metacholine revealed a severe bronchial hyperreactivity $\mathrm{PC}_{20}=0.2 \mathrm{mg} / \mathrm{ml}$. During the specific inhalation challenge test with wood dust the patient reported shortness 
Table 1. Specific IgE levels determined by the immunoenzyme assay

\begin{tabular}{lc}
\hline \multicolumn{1}{c}{ Allergen } & Concentration $(\mathrm{kU} / \mathrm{l}) /$ class \\
\hline Dust mites & $0.65 / 1.8$ \\
Formaldehyde & $<0.35 / 0$ \\
Synthetic fibres & $0.77 / 2.0$ \\
Wood dust & \\
pine & $1.20 / 2.2$ \\
oak & $1.51 / 2.3$ \\
obeche & $0.97 / 2.1$ \\
\hline
\end{tabular}

Reference values: $<0.35 \mathrm{kU} / \mathrm{l}$ - negative result (class 0$)$; 0.35-0.7 kU/1low concentration (class 1); 0.7-3.5 kU/1 - moderate concentration (class 2); 3.5-17.5 kU/1 - high concentration (class 3); > $17.5 \mathrm{kU} / 1$ - very high concentration (class 4 ).

of breath, which was the most severe during the first $2 \mathrm{~h}$ after the challenge. Dyspnea, reported by the patient, developed already during the specific inhalation challenge test with the greatest intensity right after the test. Auscultation revealed numerous whistles $5 \mathrm{~min}$ after starting SICT, $2 \mathrm{~h}$ and $4 \mathrm{~h}$ after the challenge. The daily change in $\mathrm{FEV}_{1}$ and PEF values after the challenge with placebo and with samba wood dust are presented in Figure 1.

The greatest declines in $\mathrm{FEV}_{1}$ i.e. of $18 \%$ compared to the baseline was observed in the 2nd and the 5 th $\mathrm{h}$ after the challenge test with wood dust. Decrease in PEF was

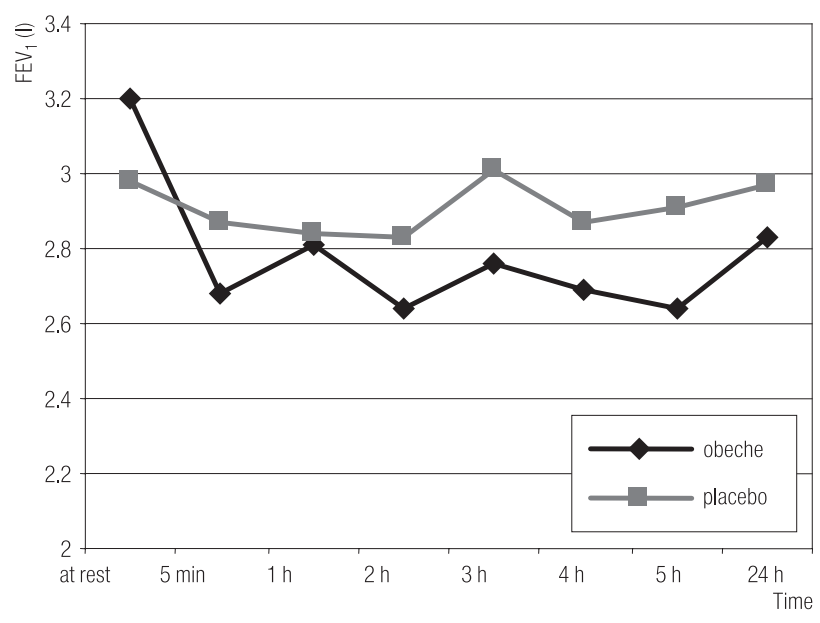

Fig. 1. Changes in $\mathrm{FEV}_{1}$ across 24-hours after specific challenge test with obeche wood dust and placebo

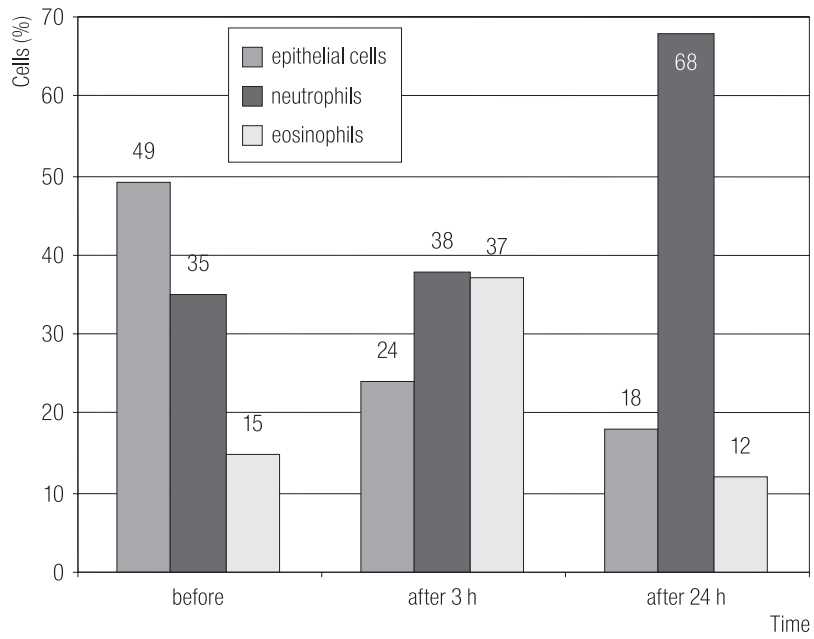

Fig. 2. Morphological changes in nasal lavage fluid before and after specific challenge test

also the highest $2 \mathrm{~h}$ after the specific challenge test and it amounted to $24 \%$ compared to PEF prior to the challenge. Morphological evaluation of nasal lavage fluid after the inhalation challenge test with samba wood dust revealed the inflow of neutrophils, eosinophils and a slight increase in the percentage of basophils. An increased percentage of eosinophils $4 \mathrm{~h}$ after the challenge test, neutrophils $24 \mathrm{~h}$ after the challenge test, and basophils, $4 \mathrm{~h}$ and $24 \mathrm{~h}$ after the specific challenge test was observed, while a number of epithelial cells was reduced (Figure 2).

Two-fold increase in the percentage of eosinophils in the induced sputum was observed $24 \mathrm{~h}$ after the SICT (Table 2).

\section{DISCUSSION}

Samba (Triplochiton scleroxylon) is a tropical tree, which grows mostly at transition zone between wet evergreen forests and tress which partially shed leaves. The samba wood is usually light-straw, yellow-brown or creamy-white in color. Data on the frequency of exposure to exotic wood dust in Poland are lacking, but it seems that the increasing use of these materials may result in health problems in the exposed workers. 
Table 2. Morphological changes in induced sputum after specific inhalation challenge test (SICT)

\begin{tabular}{lccccc}
\hline \multirow{2}{*}{$\begin{array}{c}\text { Time of sputum } \\
\text { collection }\end{array}$} & \multicolumn{5}{c}{$\begin{array}{c}\text { Cells in induced sputum } \\
(\%)\end{array}$} \\
\cline { 2 - 6 } & epithelial cells & neutrophils & eosinophils & basophils & monocytes \\
\hline Before SICT & 24 & 47 & 3 & 1 & 0 \\
24 h after SICT & 13 & 56 & 6 & 2 & 0 \\
\hline
\end{tabular}

Sensitization to samba wood allergens is an interesting allergological problem, as the IgE-dependent allergic reactions, which are not typical for wood dusts allergens $[15,16]$ were observed. For example, in the case of allergy to red cedar dust in approximately $30 \%$ of exposed population SPT to plicatic acid (PA) are positive or the specific $\mathrm{IgE}$ antibodies for PA are detected [17]. Therefore, the diagnosis and confirmation of occupational respiratory allergy to wood dust cannot be based only on the results of skin prick tests or the presence of specific serum IgE. SICT is considered as a 'gold standard' or 'reference standard' but fall in $\mathrm{FEV}_{1}$ value may be due to irritating effect of wood dust. To differentiate this and confirm allergic reaction the other objective method i.e. morphological changes in induced sputum could be helpful.

The majority of data on asthma due to samba wood dust is based on case reports, therefore, it is difficult to determine the incidence of sensitization to these allergens. Cases of IgE-dependent allergic reactions to plicatic acid from red cedar, as well as single cases of allergy to pine and spruce were also reported [18]. In our wood dust allergens panel used for the SPT we included species that typically grow in our country and, for the described patient, samba allergens were additionally used. The patient suffered from symptoms typical for bronchial asthma. In the case of asthma due to samba wood dust symptoms are the same as in the asthma caused by other antigens. However, a characteristic feature of asthma caused by wood dust is the occurrence of first symptoms after work, often at night a few hours after allergen exposure. Later on, the symptoms begin to occur immediately after contact with wood dust, which is associated with late acute asthmatic reaction to the allergen at the beginning followed by development of a 2-phase reaction [19-21].

The patient reported typical asthma symptoms occurring quite immediately after entering the workplace. Positive SPTs with common aeroallergens and occupational allergens, also with samba tree allergens, were found. However, sensitization to common allergens does not exclude recognition of occupational respiratory disease, and positive SPTs results are not conclusive of the necessity of developing symptoms of allergic disease like allergic rhinitis or asthma. Sensitization to common allergens and an elevated total serum IgE level in the described patient confirmed the presence of atopy. Atopy increases the risk of development of occupational asthma due to sensitization to the high molecular weight allergens [22-25]. It was observed in bakers and farmers exposed to flowers and animals allergens [26-28]. There is no sufficiently proved relationship between atopy and occupational sensitization in the case of allergy to wood dust allergens, which are classified as the low molecular weight allergens. It is considered that atopy does not predispose to wood dust induced asthma, although some studies have suggested that it is an important modifying factor. According to Sjostedt et al. asthma occurs more often in atopic workers exposed to wood dust than in atopic population not exposed to such allergens [29].

Spirometry measurements, carried out when the patient was not exposed to occupational allergens, showed a mild airway obstruction that could suggest COPD due to 35 packyears history of smoking. However, bronchial reversibility and significant bronchial hyperresponsiveness, which are an integral part of a clinical course of asthma, supported 
asthma diagnosis. SICT with workplace allergens is the gold standard in diagnosis of occupational asthma [30].

When asthma due to wood dust is suspected, apart from spirometry measurements monitoring, the cellular changes in induced sputum should be evaluated to exclude irritation by the dust itself. SICT is generally considered positive when fall in $\mathrm{FEV}_{1}$ of at least $15 \%$ from pre-challenge value is recorded at the time of an immediate reaction (ERS consensus not published yet). In our case $18 \%$ fall in $\mathrm{FEV}_{1}$ was recorded in the 2 nd and the 5 th $\mathrm{h}$ after the SOCT. It is suggested by some evidence that in the case of a delayed reaction, $\mathrm{FEV}_{1}$ fall $\geq 15 \%$ may be considered as positive SICT [31-35]. In the presented case occupational history of asthma symptoms, type of exposure, positive results of SPT to occupational allergens, the high level of bronchial hyperresponsiveness as well as significant decrease in $\mathrm{FEV}_{1}$ and clinical symptoms with bronchial obstruction induced by the specific challenge test confirmed a positive reaction to the occupational allergen. Additionally, evaluation of cellular changes in nasal lavage fluid and induced sputum in the patient revealed a significant, more than 2-fold, increase in eosinophil proportion. Due to those findings occupational asthma and allergic rhinitis were recognized.

This case of allergy to exotic Triplochiton scleroxylon wood is the first one described in Poland. Samba wood, apart from model making, is also used in the industry, which makes it a potential occupational allergen. Therefore, special attention should be paid to the workers involved in mechanical wood processing as a population at risk of occupational allergy.

\section{REFERENCES}

1. Jacobsen G, Schaumburg I, Sisgaard T, Schlunssen V. Nonmalignant respiratory diseases and occupational exposure to wood dust. Part II. Dry wood industry. Ann Agric Environ Med. 2010;17(1):29-44.
2. Enarson DA, Chan-Yeung M. Characterization of health effects of wood dust exposures. Am J Ind Med. 1990;17(1): 33-8, http://dx.doi.org/10.1002/ajim.4700170107.

3. Goldsmith DF, Shy CM. Respiratory health effects in a group of North Carolina furniture workers. J Occup Med. 1988;(14):1-15.

4. Ricciardi L, Fedele R, Saitta S, Tigano V, Mazzeo L, Fogliani $\mathrm{O}$, et al. Occupational asthma due to exposure to iroko wood dust. Ann Allergy Asthma Immunol. 2003;91(4): 393-7, http://dx.doi.org/10.1016/S1081-1206(10)61687-0.

5. Bohadana AB, Massin N, Wild P, Toamain JP, Engel S, Goutet P. Symptoms, airway responsiveness and exposure to dust in beech and oak woodworkers. Occup Environ Med. 2000;57:268-73, http://dx.doi.org/10.1136/oem. 57.4.268.

6. Chang-Yeung M. Mechanism of occupational asthma due to western red cedar (Thuja plicata). Am J Ind Med. 1994;25: 13-8, http://dx.doi.org/10.1002/ajim.4700250106.

7. Reijula K, Kujala V, Latvala J. Sauna builder's asthma caused by obeche (Triplochiton scleroxylon) dust. Thorax. 1994;49:622-3, http://dx.doi.org/10.1136/thx.49.6.622.

8. Vedal S, Chan-Yeung M, Enarson D, Fera T, Maclean L, Tse KS, et al. Symptoms and pulmonary function in western red cedar workers related to duration of employment and dust exposure. Arch Environ Health. 1986;41(3):179-83, http://dx.doi.org/10.1080/00039896.1986.9935774.

9. Yeung M. Immunological and nonimmunological mechanisms in asthma due to western red cedar (Thuja plicata). J Allergy Clin Immunol. 1982;70:32-7, http://dx.doi.org/ 10.1016/0091-6749(82)90198-1.

10. Reijula K, Kujala V, Latvala J. Sauna builder's asthma caused by obeche (Triplochiton scleroxylon) dust. Thorax. 1994;49:622-3, http://dx.doi.org/10.1136/thx.49.6.622.

11. Hinojosa M, Moneo I, Dominguez J, Delgado E, Losada E, Alcover R. Asthma caused by African maple (Triplochiton scleroxylon) wood dust. J Allergy Clin Immunol. 1984;74:782-6, http://dx.doi.org/10.1016/0091-6749 (84)90179-9. 
12. Global Initiative for Chronic Obstructive Lung Disease (GOLD). Global strategy for the diagnosis, management, and prevention of chronic obstructive pulmonary disease. Available from: http://www.goldcopd.org/uploads/users/ files/GOLDReport_April112011.pdf.

13. Cockcroft DW. Bronchoprovocation methods: direct challenges. Clin Rev Allergy Immunol. 2003;24(1):19-26, http:// dx.doi.org/10.1385/CRIAI:24:1:19.

14. Pepys J, Hutchcroft BJ. Bronchial provocation tests in etiologic diagnosis and analysis of asthma. Am Rev Respir Dis. 1975;112(6):829-59.

15. Pontier JP, Popin E, Kopferschmitt-Kubler MC, Bessot JC, Pauli G. [Asthma from tropical abachi wood]. Rev Pneumol Clin. 2002;58(5):282-5. French.

16. Ferrer A, Maranon F, Casanovas M, Fernandez-Caldas E. Asthma from inhalation of Triplochiton scleroxylon (Samba) wood dust. J Investig Allergol Clin Immunol. 2001;11(3): 199-203.

17. Chan-Yeung M, Malo JL. Western Red Cedar (Thuja plicata) and other wood dusts. In: Bernstein D, Chan-Yeung M, Malo JL, Bernstein IL, editors. Asthma in workplace. New York: Taylor \& Francis; 2006. p. 505-24.

18. Schlünssen V, Kespohl S, Jacobsen G, Raulf-Heimsoth M, Schaumburg I, Sisgaard T. Immunoglobin E-mediated sensitization to pine and beech dust in relation to wood dust exposure levels and respiratory symptoms in furniture industry. Scand J Work Environ Health. 2011;37(2):159-67, http:// dx.doi.org/10.5271/sjweh.3087.

19. Goldsmith DF, Shy CM. Respiratory health effects from occupational exposure to Wood dusts. Scan J Work Environ Health. 1988;14:1-15, http://dx.doi.org/10.5271/sjweh.1958.

20. Enarson DA, Chan Yeung M. Characterization of health effects of wood dust exposures. Am J Ind Med. 1990;17:33-8, http://dx.doi.org/10.1002/ajim.4700170107.

21. Chan-Yeung M, Malo JL. Occupational respiratory diseases associated with forest product industries. In: Harber P, Schenker M, Balmes J, editors. Occupational respiratory disease. St. Louis: Mosby; 1996. p. 637-53.
22. Peden DB. Development of atopy and asthma: candidate environmental influences and important periods of exposure. Environ Health Perspect. 2000;108(3):475-82.

23. Arruda LK, Solé D, Baena-Cagnani CE, Naspitz CK. Risk factors for asthma and atopy. Curr Opin Allergy Clin Immunol. 2005;5(2):153-9, http://dx.doi.org/10.1097/01.all. 0000162308.89857.6c.

24. Lemière C, Charpin D, Vervloet D. [Is atopy a risk factor of occupational asthma?]. Rev Mal Respir. 1995;12(3):231-9. French.

25. Venables KM, Tee R, Hawkins E, Gordon DJ, Wale CJ, Farrer NM, et al. Laboratory animal allergy in a pharmaceuticals company. Br J Ind Med. 1988;45:600-6.

26. De Zotti R, Bovenzi M. Prospective study of work-related respiratory symptoms in trainee bakers. Occup Environ Med. 2000;57:58-61, http://dx.doi.org/10.1136/oem.57.1.58.

27. Gautrin D, Ghezzo H, Infante-Rivard C, Malo JL. Natural history of sensitisation, symptoms and occupational diseases in apprentices exposed to laboratory animals. Eur Respir J. 2001;17:904-8, http://dx.doi.org/10.1183/09031936.01. 17509040.

28. Sjostedt L, Willers S, Orbaek P. A follow-up study of laboratory animal exposed workers: The influence of atopy for the development of occupational asthma. Am J Ind Med. 1993;24: 459-69, http://dx.doi.org/10.1002/ajim.4700240410.

29. Schlünssen V, Schaumburg I, Heederik D, Taudorf E, Sigsgaard T. Indices of asthma among atopic and non-atopic woodworkers. Occup Environ Med. 2004;61(6):504-11, http://dx.doi.org/10.1136/oem.2003.007815.

30. Banks DE. Use of the specific challenge in the diagnosis of occupational asthma: A 'gold standard' test or a test not used in current practice of occupational asthma? Curr Opin Allergy Clin Immunol. 2003;3(2):101-7, http://dx.doi. org/10.1097/00130832-200304000-00003.

31. Stenton SC, Avery AJ, Walters EH, Hendrick DJ. Statistical approaches to the identification of late asthmatic reactions. Eur Respir J. 1994;7:806-12, http://dx.doi.org/10.1183/09031 936.94.07040806. 
32. Moore VC, Jaakkola MS, Burge CB, Robertson AS, Pantin $\mathrm{CF}$, Vellore $\mathrm{AD}$, et al. A new diagnostic score for occupational asthma: The area between the curves $(\mathrm{ABC}$ score) of peak expiratory flow on days at and away from work. Chest. 2009;135:307-14, http://dx.doi.org/10.1378/ chest.08-0778.

33. Burge CB, Moore VC, Pantin CF, Robertson AS, Burge PS. Diagnosis of occupational asthma from time point differences in serial PEF measurements. Thorax. 2009;64:1032-6, http://dx.doi.org/10.1136/thx.2009.120923.
34. Anees W, Blainey D, Moore VC, Robertson K, Burge PS. Differentiating occupational asthmatics from non-occupational asthmatics and irritant-exposed workers. Occup Med. 2011;61:190-5, http://dx.doi.org/10.1093/occmed/kqr023.

35. Baur X, Huber H, Degens PO, Allmers H, Ammon J. Relation between occupational asthma case history, bronchial methacholine challenge, and specific challenge test in patients with suspected occupational asthma. Am J Ind Med. 1998;33:114-22, http://dx.doi.org/10.1002/(SICI)10970274(199802)33:2\%3C114::AID-AJIM3\%3E3.0.CO;2-Y.

This work is available in Open Access model and licensed under a Creative Commons Attribution-NonCommercial 3.0 Poland License - http://creativecommons.org/ licenses/by-nc/3.0/pl/deed.en. 